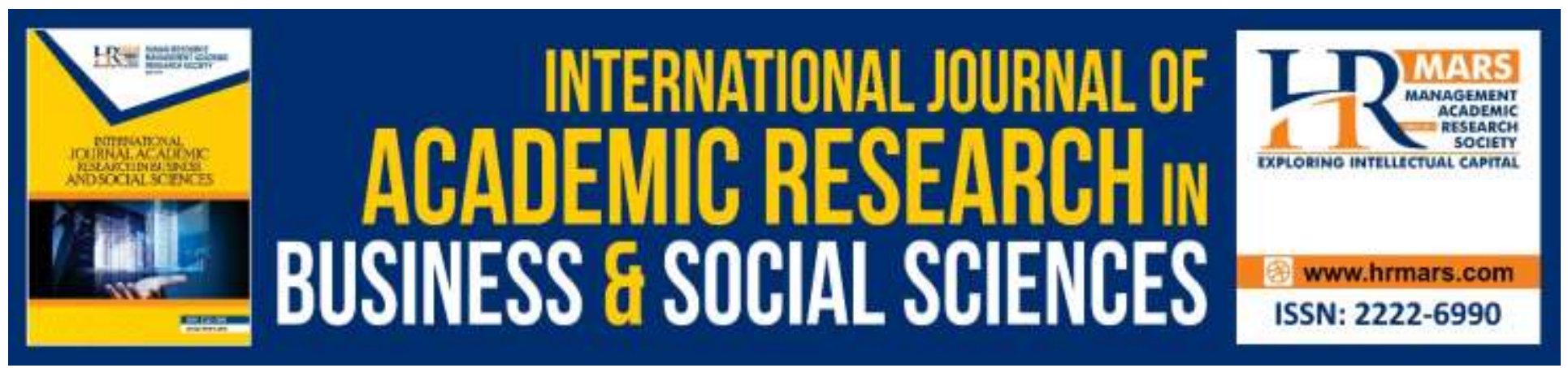

\title{
Construct Validity and Reliability of Manufacturing Industry: A Rasch Measurement Model Approaches for Pilot Study
}

Muhamad Shazielan Sharif, Zaliza Hanapi, Irdayanti Mat Nashir, Che Ghani Che Kob, Arman Shah Abdullah

To Link this Article: http://dx.doi.org/10.6007/IJARBSS/v9-i3/5733

DOI:10.6007/IJARBSS/v9-i3/5733

Received: 09 Feb 2019, Revised: 27 Feb 2019, Accepted: 15 March 2019

Published Online: 19 March 2019

In-Text Citation: (Sharif, Hanapi, Nashir, Kob, \& Abdullah, 2019)

To Cite this Article: Sharif, M. S., Hanapi, Z., Nashir, I. M., Kob, C. G. C., \& Abdullah, A. S. (2019). Construct Validity and Reliability of Manufacturing Industry: A Rasch Measurement Model Approaches for Pilot Study. International Journal of Academic Research in Business and Social Sciences, 9(3), 654-664.

Copyright: (C) 2019 The Author(s)

Published by Human Resource Management Academic Research Society (www.hrmars.com)

This article is published under the Creative Commons Attribution (CC BY 4.0) license. Anyone may reproduce, distribute, translate and create derivative works of this article (for both commercial and non-commercial purposes), subject to full attribution to the original publication and authors. The full terms of this license may be seen

at: http://creativecommons.org/licences/by/4.0/legalcode

Vol. 9, No. 3, 2019, Pg. 654 - 664

Full Terms \& Conditions of access and use can be found at http://hrmars.com/index.php/pages/detail/publication-ethics 


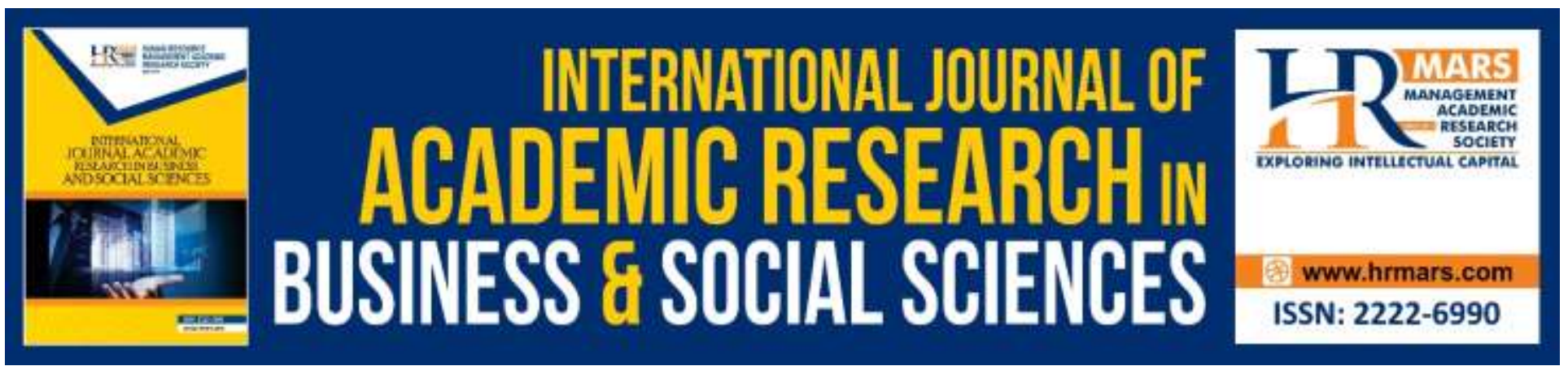

\section{Construct Validity and Reliability of Manufacturing Industry: A Rasch Measurement Model Approaches for Pilot Study}

\section{Muhamad Shazielan Sharif, Zaliza Hanapi, Irdayanti Mat Nashir, Che Ghani Che Kob, Arman Shah Abdullah}

Department of Engineering Technology, Faculty of Technical and Vocational, Universiti Pendidikan Sultan Idris, 35900 Tanjong Malim, Perak Darul Ridzuan, Malaysia.

\section{Abstract}

This pilot study was conducted to examine and verify the reliability of instruments for the manufacturing industry in Malaysia. The manufacturing industry instruments that had been prepared consists of 88 items and is distributed to 40 female workers from several factories located in Kedah, Perak, and Selangor. The purpose of the establishment of this instrument is to measure the three main constructs of this study, which is; (1) career aspiration; (2) job satisfaction; and (3) career development. The approach used to examine the validity and reliability of the items and respondents in this study is emanate from the Rasch Measurement Model Approaches which is much more valid and well-grounded compared to just focus on the output produced by Cronbach's Alpha. The Winsteps software Version 3.73 has been used to check on the functionality of the items in the aspects such as the item reliability and the separation of item-respondent, polarity item, the suitability of the item to measure the construct, the item difficulty level, and the respondent's ability. It also allows the removal of items based on the statistics of polarity item and the suitability of the item. At the end of the analysis, it is found that there is a total of 16 items that were discarded because they did not meet the inspection criteria specified in accordance to the Rasch Model. The final instrument recorded a total of 72 items that can only be used to measure the three constructs of the study. Since this study was established as a pilot study, then the distribution made to the actual respondents can be carried out in order to measure the three main constructs of this study.

Keywords: Manufacturing Industry, Validity, Reliability, Rasch Measurement Model Approach

\section{Introduction}

Nowadays, manufacturing industry is an important sector in the Malaysian economy (Habidin, Yusof, \& Fuzi, 2016; Fuzi, Habidin, \& Ong, 2017). The importance of manufacturing is to contribute to the gross domestic product (GDP) in the Malaysian economy (Hooi, 2016). This is because GDP growth is important to improve the performance of the Malaysian manufacturing industry. The instruments used in this study as such the career aspiration (CA), job satisfaction (JS) and career development 
(CD) are among the tools that can be used to improve the performance of the Malaysian manufacturing industry. However, Spencer, Adams, and Yapa (2013) mentioned that the manufacturing industry faces a gap in information systems, particularly to the environment. By measuring $C A, J S$, and $C D$, this study can help achieve the goals and improve the performance in the Malaysian manufacturing industry. To ensure that the questionnaire instrument has good validity and reliability, thus this pilot study was conducted. Subsequently, by using the Rasch Model approach, the researcher conducts an analysis to examine the validity and reliability of the questionnaire instrument. Through this approach, each item can be thoroughly checked and discusses rather than by just looking solely at the value of Cronbach's Alpha. By way of this Rasch Model approach, the researcher had conducted several analyzes such as checking and verifying the functionality of each item.

\section{Data Analysis Based on Rasch Measurement Model}

There are several diagnostic methods that are commonly used by researchers in regards to the Rasch Measurement Model. It is intended to test and examine the validity and reliability of the questionnaire instrument that had been constructed. Among them is to;

(i) Testing the reliability and the index of item and respondent separation;

(ii) Identify the polarity item that measures the constructs;

(iii) Examine the suitability of the item instrument (item fit);

(iv) Determine the item difficulty level and the ability of the respondents;

(v) Determine the structure functionality of the measurement scale category; and

(vi) Distinguish a unidimensional construct.

For this pilot study, the researcher had decided to use the Rasch Model Approach to examine the validity and reliability of a questionnaire instrument that had been developed by the researcher through the quantitative data collection. Usually, the validity and reliability of the respective items will only be discerned through the overall value of Cronbach's Alpha for that instrument.

\section{Objective}

The objective of this pilot study is to test the reliability of the instrument that has been developed and to detect its weakness. In this pilot study, the researcher had performed several inspections on the item functionality in terms of its reliability and the separation of item-respondent, polarity items, the suitability of the items and the item difficulty.

\section{Methodology}

This pilot study was carried out by using a quantitative approach by distributing the questionnaire instrument regarding the manufacturing industry to the selected respondents. The sample for this pilot study involved a total of 40 female workers which specifically consists of engineers, technicians, and supervisors only. According to Cooper and Schindler (2011), the number of respondents which is suitable and considered as adequate for the pilot study is between 25 and 100 people. Meanwhile, Johanson and Brooks (2010) suggested that the minimum number of respondents for the pilot study 
is 30 people with the aim of being preliminary research or a scale development. The findings generated from this pilot study will then be analyzed using the Winsteps software Version 3.73 alongside the Rasch Measurement Model Approach. The manufacturing industry instrument that had been constructed consists of 88 items which comprises the three main constructs, namely career aspiration, job satisfaction, and career development.

\section{Results and Findings}

In accordance with the Rasch Measurement Model Approach, the researcher had conducted a test on the functionality of the item in terms of (i) the item reliability and the separation of itemrespondent; (ii) identify the polarity items that measure the constructs of the study based on the value of PTMEA CORR; (iii) the suitability (fit) item that measures the constructs of the study; and (iv) the map of item-respondent difficulty level in this study. The description and explanation for each item tested on the functionality are as follows.

\section{Reliability and Item Separation}

Based on the Rasch Measurement Model Approach, the value of Cronbach's Alpha ( $\alpha)$ that its reliability can be accepted is between $0.71-0.99$ where this value is at its best $(71 \%-99 \%)$ as described in Table 1.0 (Bond \& Fox, 2007).

Table 1.0: The Interpretation of Cronbach's Alpha Score

\begin{tabular}{cc}
\hline The Score of Cronbach's Alpha & Reliability \\
\hline $0.9-1.0$ & Very good and effective with a high level of consistency \\
$0.7-0.8$ & Good and is acceptable \\
$0.6-0.7$ & Acceptable \\
$<0.6$ & The item needs refinement \\
$<0.5$ & The item needs to be discarded \\
\hline
\end{tabular}

Source: (Bond \& Fox, 2007)

In order to determine the reliability of the respective items, the statistical analysis by using the Rasch Measurement Model Approach was used with reference to the reliability value and the value of the item separation. The result of the analysis found that the reliability value obtained based on Cronbach's Alpha ( $\alpha$ ) value was 0.75 as shown in Table 1.1 below. The value obtained clearly shows that the instruments used are in good condition and is acceptable, thus it can be used in real research.

Table 1.1: The Reliability Score (Cronbach's Alpha) for Pilot Study

PERSON RAW SCORE-TO-MEASURE CORRELATION $=1.00$

CRONBACH'S ALPHA (KR-20) PERSON RAW SCORE "TEST" RELIABILITY = .75

The analysis for the entire instrument was also performed by looking at the reliability value and the separation values of the items and respondents. Based on Table 1.2 as shown below, the reliability value of the item is 0.79 , which indicates that it is in good condition and is acceptable (Bond \& Fox, 2007). Meanwhile, the value of item separation is 1.92 and when rounded up is 2.0 , this value 
INTERNATIONAL JOURNAL OF ACADEMIC RESEARCH IN BUSINESS AND SOCIAL SCIENCES Vol. 9, No. 3, March, 2019, E-ISSN: 222 2-6990 @ 2019 HRMARS

can still be used because the items are new items. As suggested by Linacre (2005), the value that shows a good index separation is a value that is greater or more than the value of 2.0.

Table 1.2: Reliability and Item Separation Value for the Entire Construct Instruments: Pilot Study

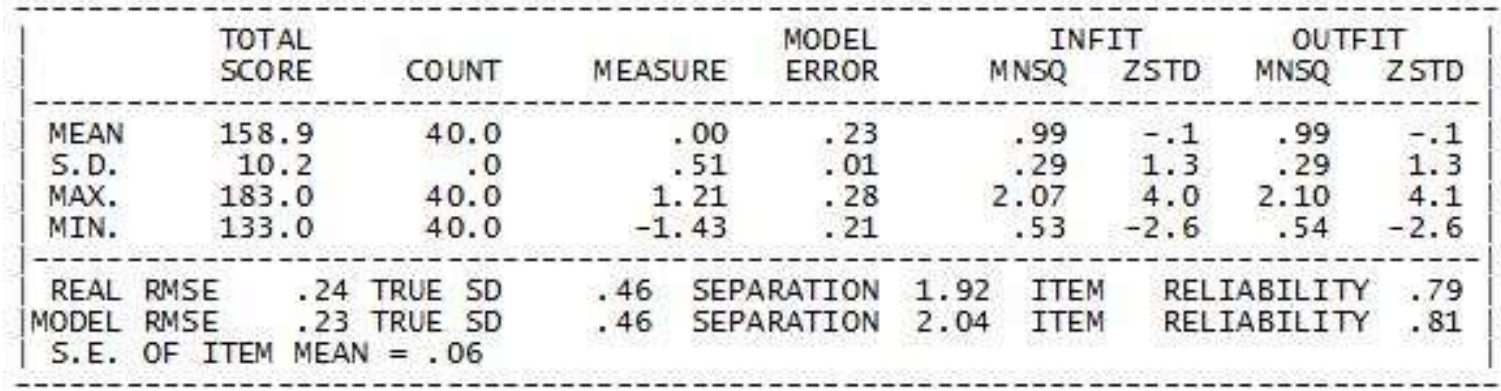

Whilst, based on Table 1.3 below, the reliability value of the respondents is 0.74 and the respondent's separation value is 1.67. This shows that the reliability of the respondents is good and acceptable. This is because Bond and Fox (2007), had explained that the reliability value which exceeds 0.71 is good and acceptable. And the respondent's separation value recorded is 1.67 and when rounded up is 2.0. The value of the item and respondent separation which is more than 2.0 is considered as good (Fox \& Jones, 1998; Linacre, 2005; Bond \& Fox, 2007).

Table 1.3: Reliability and Respondent Separation Value for the Entire Construct Instruments: Pilot Study

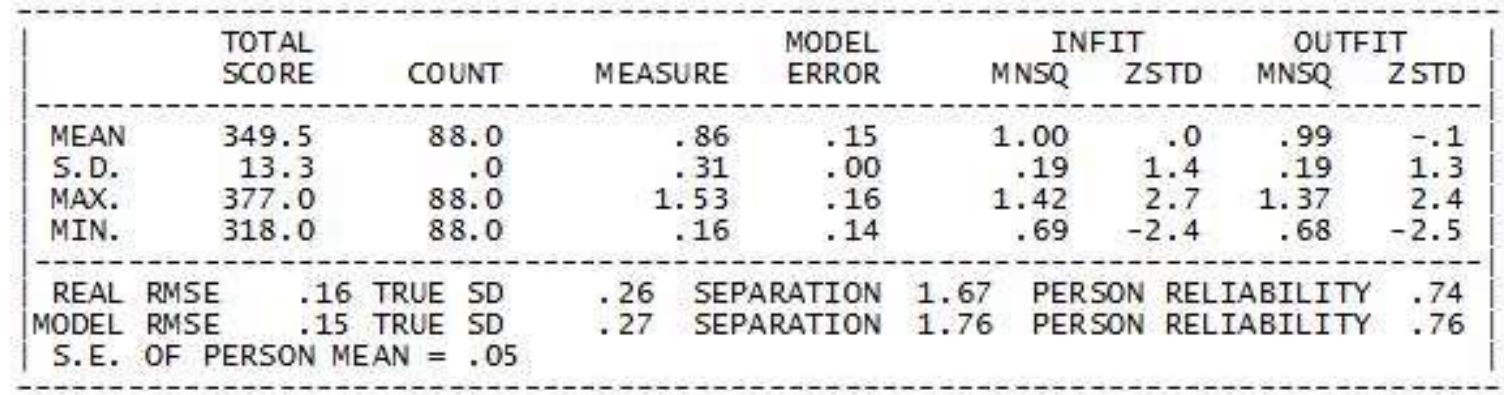

\section{Polarity Item by PTMEA CORR Value}

The Point Measure Correlation or PTMEA CORR value examination was made to identify the polarity items in the study, which is intended to test the extent of which the established constructs can achieve its goals. If the value found in the PTMEA CORR section is positive $(+)$, then it indicates the respective item can achieve its goals of measuring the construct that needs to be measured (Bond \& Fox, 2007). In contrast, if the value is negative (-), then the established item does not measure the construct that needs to be measured. So, the item needs to be revised or discarded because it does not address the question or it is too difficult for the respondents to answer it. Based on Table 1.4 below, there are four items that recorded negative values in the PRMEA CORR section which is item G3, G4, 16, and J4. These four items that have negative PTMEA CORR value indicates that the item 
should be revised or discarded. Based on the result, the four items were discarded from the 88 items in the questionnaire.

For the rest of the items, the PTMEA CORR value is positive, which indicates that the items measure the constructs that need to be computed (Bond \& Fox, 2007). Even though the PTMEA CORR value shown is positive, there are certain items with positive value but is at a very low value, which is item 06 (0.01), B3 (0.02), J5 (0.03), A4 (0.04), J1, I2, G7 (0.05), F5, J3, G1, G8 (0.06), and C6, I1, K1 (0.07). The items a with low positive value of PTMEA CORR should be noted, because very likely that the respondents will find it difficult to answer the questions (Azman Hassan, 2011). So, the process of refining the items needs to be done. However, based on the findings, it shows that the items are positively moving in one direction to measure the constructs. And it does not contradict with the constructs that need to be measured.

Table 1.4: Point Measure Correlation (PMEA CORR) Value

\begin{tabular}{|c|c|c|c|c|c|c|c|c|}
\hline $\begin{array}{l}\text { Entry } \\
\text { Number }\end{array}$ & $\begin{array}{c}\text { Point } \\
\text { Measure } \\
\text { Corr. }\end{array}$ & Item & $\begin{array}{c}\text { Entry } \\
\text { Number }\end{array}$ & $\begin{array}{c}\text { Point } \\
\text { Measure } \\
\text { Corr. }\end{array}$ & Item & $\begin{array}{c}\text { Entry } \\
\text { Number }\end{array}$ & $\begin{array}{c}\text { Point } \\
\text { Measure } \\
\text { Corr. }\end{array}$ & Item \\
\hline 39 & -.11 & G3 & 45 & .14 & $\mathrm{H} 1$ & 66 & .27 & K5 \\
\hline 40 & -.06 & G4 & 46 & .15 & $\mathrm{H} 2$ & 75 & .28 & M4 \\
\hline 55 & -.04 & 16 & 49 & .15 & $\mathrm{H} 5$ & 27 & .30 & E2 \\
\hline 60 & -.03 & $J 4$ & 48 & .15 & $\mathrm{H} 4$ & 25 & .31 & D7 \\
\hline 88 & .01 & 06 & 11 & .15 & B6 & 53 & .31 & 14 \\
\hline 8 & .02 & B3 & 87 & .15 & 05 & 9 & .32 & B4 \\
\hline 61 & .03 & $\mathrm{~J} 5$ & 41 & .16 & G5 & 14 & .33 & $\mathrm{C} 3$ \\
\hline 4 & .04 & A4 & 38 & .16 & $\mathrm{G} 2$ & 76 & .33 & M5 \\
\hline 57 & .05 & $\mathrm{~J} 1$ & 79 & .16 & $\mathrm{~N} 2$ & 13 & .33 & $\mathrm{C} 2$ \\
\hline 52 & .05 & 12 & 70 & .17 & L4 & 32 & .33 & F2 \\
\hline 43 & .05 & G7 & 29 & .17 & E4 & 73 & .34 & M2 \\
\hline 35 & .06 & F5 & 67 & .21 & L1 & 65 & .34 & K4 \\
\hline 59 & .06 & $\mathrm{~J} 3$ & 82 & .21 & N5 & 78 & .35 & N1 \\
\hline 37 & .06 & G1 & 84 & .21 & $\mathrm{O} 2$ & 68 & .35 & L2 \\
\hline 44 & .06 & G8 & 69 & .22 & L3 & 36 & .36 & F6 \\
\hline 17 & .07 & $\mathrm{C} 6$ & 33 & .22 & F3 & 30 & .37 & E5 \\
\hline 50 & .07 & 11 & 16 & .23 & $\mathrm{C} 5$ & 2 & .37 & $\mathrm{~A} 2$ \\
\hline 62 & .07 & K1 & 28 & .23 & E3 & 18 & .38 & $\mathrm{C7}$ \\
\hline 42 & .08 & G6 & 71 & .23 & L5 & 23 & .39 & D5 \\
\hline 86 & .09 & O4 & 47 & .23 & $\mathrm{H} 5$ & 24 & .39 & D6 \\
\hline 56 & .09 & 17 & 7 & .24 & B2 & 1 & .41 & $\mathrm{~A} 1$ \\
\hline 83 & .09 & O1 & 15 & .25 & $\mathrm{C} 4$ & 31 & .42 & F1 \\
\hline 85 & .09 & O3 & 72 & .25 & M1 & 19 & .44 & D1 \\
\hline 80 & .10 & N3 & 51 & .25 & 12 & 5 & .45 & A5 \\
\hline 81 & .12 & N4 & 58 & .26 & $\mathrm{~J} 2$ & 6 & .46 & B1 \\
\hline 10 & .12 & B5 & 63 & .26 & K2 & 64 & .46 & K3 \\
\hline 74 & .12 & M3 & 77 & .27 & M6 & 34 & .47 & F4 \\
\hline 20 & .14 & D2 & 54 & .27 & 15 & 12 & .53 & C1 \\
\hline 21 & .14 & D3 & 26 & .27 & $\mathrm{E} 1$ & 3 & .55 & A3 \\
\hline 22 & .14 & D4 & & & & & & \\
\hline
\end{tabular}

\section{Item Fit in Measuring the Constructs}

Item fit measured the constructs through the infit and outfit Mean Square (MNSQ). According to Bond and Fox (2007), the outfit and infit MNSQ should be in the range of 0.60 to 1.40 to ensure that the items are suitable for measuring the constructs. But the outfit index MNSQ noteworthy in 
advance compared infit MNSQ for determining congruity of items that measure a construct or latent variable (Kashfi, 2011). If the infit or outfit MNSQ value more than 1.40 logit, then it gives the meaning of confusing item. If the MNSQ value is less than 0.60 logit, it shows that the item is too easily anticipated by the respondents (Linacre, 2007). Beside that the outfit and infit ZSTD value should also be within -2.00 to +2.00 (Bond \& Fox, 2007). But if the outfit and infit MNSQ be accepted, then the ZSTD index can be ignored (Linacre, 2007).

Therefore, if this condition is not met, then the item should be either removed or revised. The Table 1.5 below shows the misfit order featuring six items having the largest MNSQ and six items of value resulting from the smallest MNSQ item analysis statistics: misfit order. Based on Table 1.5 below, found that 12 items that are not in the specified range and it should be revised or discarded. Items that exceed the value of 1.40 in column outfit MNSQ is A4 (2.10), A5 (1.88), I1 (1.67), N3 (1.53), $I 7$ (1.50) and G1 (1.47). Whereas a value that is less than 0.60 are items D2 (0.58), D3 (0.58), D4 (0.58), L5 (0.56), $\mathrm{O} 1$ (0.54) and 05 (0.54). Thus, from this diagnosis, there were a total of 12 items that are being removed.

Table 1.5: Item Fit Based on MNSQ Value 
INTERNATIONAL JOURNAL OF ACADEMIC RESEARCH IN BUSINESS AND SOCIAL SCIENCES Vol. 9, No. 3, March, 2019, E-ISSN: 222 2-6990 @ 2019 HRMARS

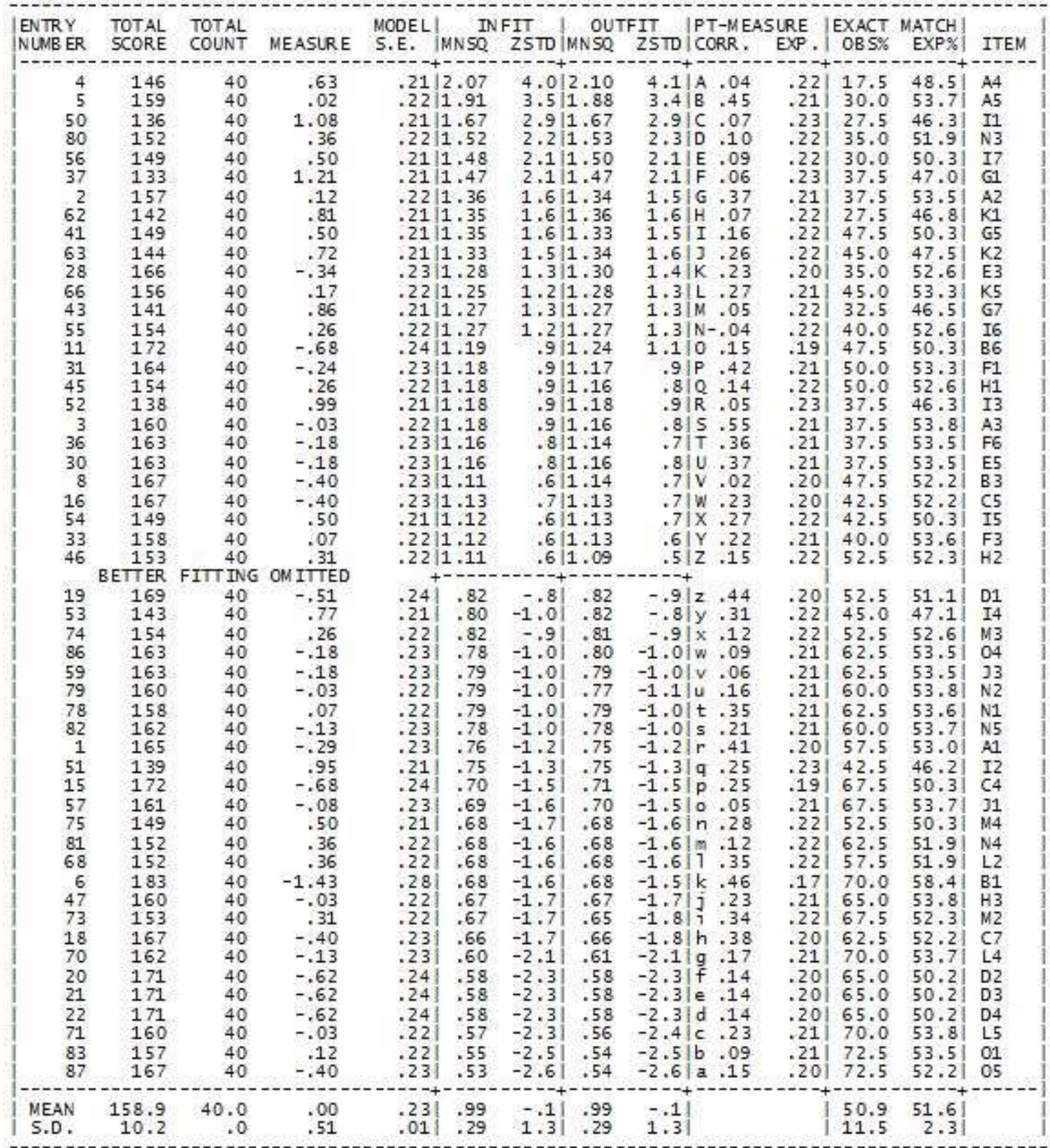

\section{Item Difficulty and Respondent's Ability}

Figure 1.6 below represents item difficulty locations and distribution of examinees along the logit scale. Item difficulty measures from +1.21 to -1.43 logit. Meanwhile, the respondents' ability estimates from +1.53 to 0.16 , which is slightly higher than the item difficulty measurement. The mean for both measurements is approximately around the same location, thus indicating that the items for this sample are well targeted. The map has greatly assisted the researcher in locating the area where most items are located particularly to see whether this is parallel with the spread of the respondents. 


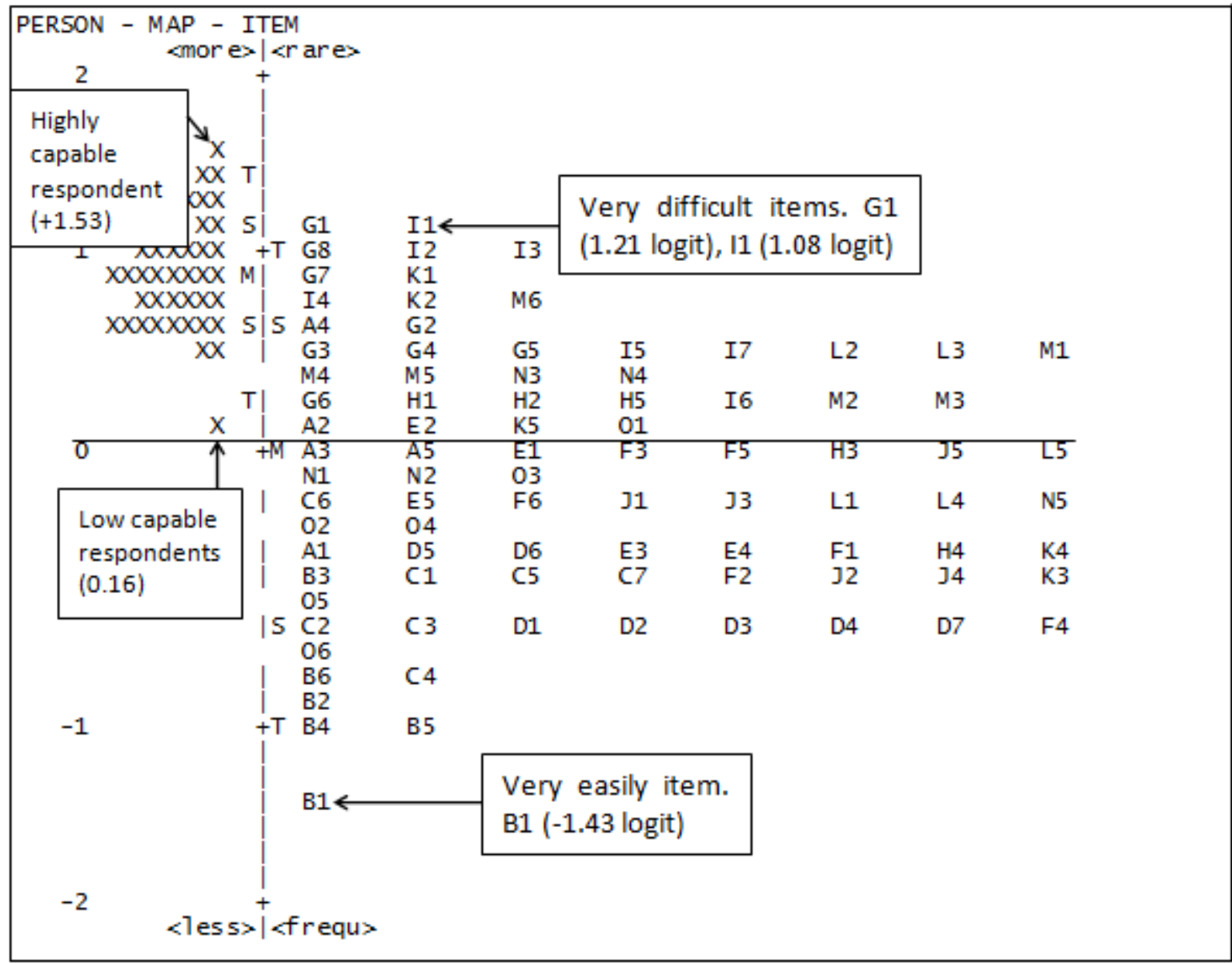

Figure 1.6: Items map of Manufacturing Industry Instrument

Figure 1.6 shows the number of respondent's ability and item difficulty on the logit scale. All the items are scattered and point towards the ability of respondents' diversity. Respondents that have high satisfaction located at the above on the scale, while the respondents that have low satisfaction are located below on the scale. The most difficult items are Job Satisfaction: G1 (1.21 logit) and II (1.08 logit) which located on the upper scale. While the easiest item is Career Aspiration: B1 (-1.43 logit). This shows that the difficult items can be answered by the highly capable respondents, while the easier item can be easily answered by the respondents of high ability and low ability (Linacre, 2007).

\section{Discussions and Conclusion}

After data analysis, each item is being revised following the standard index and the conditions that must be followed to achieve the standards of validity and reliability of the instrument based on the Rasch measurement model. The item removal and purification were conducted by referring and considering the views and expert evaluation. 
INTERNATIONAL JOURNAL OF ACADEMIC RESEARCH IN BUSINESS AND SOCIAL SCIENCES Vol. 9, No. 3, March, 2019, E-ISSN: 222 2-6990 @ 2019 HRMARS

Based on the results obtained, there are 16 items that do not meet the requirements analysis and should be discarded. Whereas 14 items are appropriately refined in accordance with the context and significance of the study. Overall summary of the related items in the questionnaire is shown in Table 1.7 below.

Table 1.7: The Summary of Items Dropped and Retained

\begin{tabular}{|c|c|c|c|c|c|}
\hline Bil & Construct & Retained Item & $\begin{array}{c}\text { Total Items } \\
\text { Retained }\end{array}$ & $\begin{array}{c}\text { Item } \\
\text { Dropped }\end{array}$ & $\begin{array}{l}\text { Total Item } \\
\text { Dropped }\end{array}$ \\
\hline 1 & $\begin{array}{l}\text { Career Aspiration } \\
\text { (CA) }\end{array}$ & $\begin{array}{l}\mathrm{A} 1, \mathrm{~A} 2, \mathrm{~A} 3, \mathrm{~B} 1, \\
\mathrm{~B} 2, \mathrm{~B} 3, \mathrm{~B} 4, \mathrm{~B} 5, \\
\mathrm{~B} 6, \mathrm{C} 1, \mathrm{C} 2, \mathrm{C} 3, \\
\mathrm{C} 4, \mathrm{C} 5, \mathrm{C} 6, \mathrm{C} 7\end{array}$ & 16 & $\mathrm{~A} 4, \mathrm{~A} 5$ & 2 \\
\hline 2 & Job Satisfaction (JS) & $\begin{array}{l}\text { D1, D5, D6, D7, } \\
\text { E1, E2, E3, E4, } \\
\text { E5, F1, F2, F3, } \\
\text { F4, F5, F6, G2, } \\
\text { G5, G6, G7, G8, } \\
\text { H1, H2, H3, H4, } \\
\text { H5, I2, I3, I4, I5, } \\
\mathrm{J} 1, \mathrm{~J} 2, \mathrm{~J} 3, \mathrm{~J} 5, \mathrm{~K} 1, \\
\mathrm{~K} 2, \mathrm{~K} 3, \mathrm{~K} 4, \mathrm{~K} 5\end{array}$ & 38 & $\begin{array}{l}\mathrm{D} 2, \mathrm{D} 3, \mathrm{D} 4, \\
\mathrm{G} 1, \mathrm{G} 3, \mathrm{G} 4, \\
\mathrm{I} 1,16, \mathrm{I}, \mathrm{J} 4\end{array}$ & 10 \\
\hline 3 & $\begin{array}{l}\text { Career Development } \\
\text { (CD) }\end{array}$ & $\begin{array}{l}\text { L2, L3, L4, L5, } \\
\text { M1, M2, M3, } \\
\text { M4, M5, M6, } \\
\text { N1, N2, N4, N5, } \\
\text { O2, O3, O4, O6 }\end{array}$ & 18 & $\begin{array}{l}\mathrm{L} 1, \mathrm{~N} 3, \mathrm{O} 1, \\
\mathrm{O} 5\end{array}$ & 4 \\
\hline \multicolumn{2}{|c|}{ Total } & & 72 & & 16 \\
\hline
\end{tabular}

Based on this research, it can be concluded that the validity and reliability of an instrument are a very important aspect to consider in developing a new instrument for a study. Overall from this analysis, it is found that a total of 16 items that were dropped are questionable items on validity and reliability. Thus, based on the validity and reliability test made on this instrument, it indicates that this instrument is fits to be used by companies or other researchers for future study. The implications of this analysis help researchers in developing a good instrument for the industry.

It help Human Resources by using this instrument to test women workers in this industry of manufacturing either they fulfill or not. For industry manufacturing in Malaysia, this instruments help them to provide a credibility women workers in this industry. For women workers itself, this instruments must fulfill by the women workers in this industry manufacturing, if not fulfill the criteria they should find related training, seminar or courses about manufacturing industry in Malaysia. 
INTERNATIONAL JOURNAL OF ACADEMIC RESEARCH IN BUSINESS AND SOCIAL SCIENCES

Vol. 9, No. 3, March, 2019, E-ISSN: 222 2-6990 ¿ 2019 HRMARS

\section{Acknowledgement}

The researchers would like to thank Universiti Pendidikan Sultan Idris (UPSI) for willing to help complete this study through the University Grants, Project Code 2017-0210-106-01.

\section{Corresponding Author}

Muhamad Shazielan Bin Sharif

Department of Engineering Technology, Faculty of Technical and Vocational, Universiti Pendidikan Sultan Idris, 35900 Tanjong Malim, Perak, Malaysia.

Email: shazielan@gmail.com

\section{References}

Hassan, A. (2011). Kesahan dan Kebolehpercayaan Item Penilaian Pembimbing dalam Pembelajaran Berasaskan Kerja (PBK) Menggunakan Model Pengukuran Rasch. USM, Psychometrics Centre, MIMOS \& Malaysian Examination Syndicate, MOE.

Bond, T. G., \& Fox, C. M. (2007). Applying the Rasch model: Fundamental measurement in the human sciences ( $2^{\text {nd }}$ ed.). Mahwah, New Jersey: Lawrence Erlbaum Associates.

Cooper, D. R., \& Schindler, P. S. (2011). Business research methods (11 ${ }^{\text {th }}$ edition). New York: McGraw-Hill.

Fox, C. M., \& Jones, J. A. (1998). Uses of Rasch modeling in counseling psycology research. Journal of Counselling Psychology, 45(1), 30-45.

Fuzi, N. M., Habidin, N. F., Hibadullah, S. N., \& Ong, S. Y. Y. (2017). CSR Practices, ISO 26000 and Performance Among Malaysian Automotive Suppliers. Social Responsibility Journal, 13(1), 203-220.

Habidin, N. F., Yusof, S. M., \& Fuzi, N. M. (2016). Lean Six Sigma, Strategic Control Systems, and Organizational Performance for Automative Suppliers. International Journal of Lean Six Sigma, 7(2), 110-135.

Wan, H. L. (2016) The Manufacturing Sector in Malaysia. In: Organisational Justice and Citizenship Behaviour in Malaysia. Governance and Citizenship in Asia. Springer, Singapore. 2136. Doi: 10.1007/978-981-10-0030-0_2.

Johanson, G. A., \& Brooks, G. P. (2010). Initial scale development: sample size for pilot studies. Educational and Psychological Measurement, 70(3), 394-400.

Linacre, J. M. (2005). Test validity, and Rasch measurement: Construct, content, etc. Rasch Measurement Transactions.

Linacre, J. M. (2007). A user's guide to WINSTEPS Rasch-model computer programs. Chicago, Illinois: MESA Press.

Jailani, M. K. M. (2011). Manual Pengenalan Pengukuran Rasch \& Winsteps. Pengukuran dan Penilaian dalam Pendidikan. Fakulti Pendidikan Universiti Kebangsaan Malaysia.

Spencer, S. Y., Adams, C., \& Yapa, P. W. S. (2013). The Mediating Effects of the Adoption of an Environmental Information System on Top Management's Commitment and Environmental Performance. Sustainability Accounting, Management and Policy Journal, 4(1), 75-102. Doi: 10.1108/SAMPJ-10-2011-0030. 